\title{
MARKETING JAKO PROCES TWORZENIA WARTOŚCI W DOBIE PANDEMII COVID-19
}

DOI: $10.33141 /$ po.2020.06.02

\section{Stanisław Brzeziński}

Przegląd Organizacji, Nr 6(965), 2020, s. 9-14

www.przegladorganizacji.pl

(๑) Towarzystwo Naukowe Organizacji i Kierownictwa (TNOiK)

\section{Wprowadzenie}

M arketing dzięki swej funkcji, jaką jest spełnianie oczekiwań klienta, obecnie przeniknął do naszego codziennego życia. Utożsamia się go ze sprzedażą, reklamą, promocjami, które w pełni koncentrują się na konsumencie. Jest to celowy sposób postępowania organizacji na rynku, które prowadzą ciągłe badania i analizy trendów zmian zachowań nabywczych konsumentów. Trendy te mogą być krótkotrwałe, przejściowe bądź długotrwałe i w związku z tym przedsiębiorstwa są zmuszone do bacznej obserwacji stylu życia społeczeństwa, bowiem świadomy klient jest dla przedsiębiorstwa czy innej instytucji największą wartością. Poznanie potrzeb i oczekiwań, a także wymagań właśnie klientów, a następnie ich zaspokojenie stanowi istotę idei marketingu. Jak pisze A. Pabian (2005, s. 8): „Organizacje realizujące prawdziwy marketing starają się przede wszystkim zadowolić klienta, a nawet go zachwycić”. Dlatego też przedsiębiorstwa czynią wszystko, by promować produkt jako wyjątkowy, niezbędny czy praktyczny, budząc zainteresowanie w jak najszerszych kręgach społeczeństwa i dbając o to, by produkt otrzymał wartość, która spełnia oczekiwania każdej jednostki. Zatem każdy podmiot zaangażowany $\mathrm{w}$ proces wymiany, kreując wartość danego produktu, liczy na zysk, a przy tym oferuje zespół korzyści potencjalnemu nabywcy. W nieustannie zmieniającym się świecie wartości pozostają niezmienne, lecz „słowa służące ich opisowi muszą ulegać zmianie, tak aby odpowiadały realiom biznesu" (Stachowicz-Stanusch, 2007, s. 70). Każda organizacja posiada zbiór wartości, ale nie każda ma tego świadomość. Trzeba pamiętać, że inaczej jest zorganizowany marketing $\mathrm{w}$ firmach produkcyjnych, a inaczej w firmach usługowych czy handlowych, zaś specyficzne rozwiązania stosuje się w poszczególnych branżach. Na pewno pracownicy każdej instytucji/jednostki znają swoją wartość, a także wartość swojej pracy dla dobra innych, to zaś daje im poczucie pewności na 
jakże turbulentnym i konkurencyjnym rynku. „Wartości są zatem spoiwem, które łączy uniwersalne ludzkie potrzeby i aspiracje z celami organizacji" (Stachowicz-Stanusch, 2007, s. 83).

W obecnych czasach mniej chodzi o produkt, a więcej o jego wartość dla klienta. Aby zaspokoić potrzeby współczesnego rynku, każdego dnia miliony kupujących zawiera miliony transakcji z milionami sprzedających. Różnorodność technologii wytwarzania dóbr i usług, wzrost wydajności produkcji, jej innowacyjność to aspekty zwiększające stopień dostępności produktów dla kupujących. Organizacje zorientowane na klienta cały czas mają na uwadze jego potrzeby, bowiem to daje im gwarancję rozwoju, wzrostu efektywności, konkurencyjności, a co najważniejsze rozpoznawalności. Zarówno klientowi, jak i organizacji powinno zależeć na dobrych relacjach, opierających się na zasadach: dbałości o interesy klienta i standardy jakościowe, działania $\mathrm{z}$ największą starannością, zachowania uczciwości i zasad fair play, solidności oraz przestrzegania ustaleń czy warunków umowy (Buchajewska-Wróbel i in., 2011, s. 134).

Marketing od kilku dziesięcioleci jest wykorzystywany przez przedsiębiorstwa, instytucje, organizacje $\mathrm{z}$ większą lub mniejszą skutecznością, niemniej jednak ma zastosowanie szczególnie w działalności gospodarczej nastawionej na zyski. Tak więc łączy się z nim rozwój produkcji, usprawnienie funkcjonowania gospodarki narodowej, zwiększenie dochodu narodowego, co $\mathrm{w}$ rezultacie prowadzi do podwyższenia poziomu stopy życiowej ludności. Ma charakter uniwersalny, a nakłady na działania marketingowe są obecnie ogromne. Marketing wymaga bowiem od przedsiębiorstwa ponoszenia mniejszych lub większych nakładów. Nakłady te związane są nie tylko $\mathrm{z}$ tworzeniem czy modernizowaniem produktów, ale też $\mathrm{z}$ organizowaniem dystrybucji, reklamą, promocją. Ten proces jest i będzie konieczny, by docierać do konsumentów i oddziaływać zarówno na nich, jak i na konkurencję. Zatem „przedsiębiorstwa powinny wykorzystać marketing do oszczędnego gospodarowania posiadanymi zasobami, a nabywcy nabrać przekonania, że pieniądze wydają racjonalnie" (Michalski, 2017, s. 32).

Celem artykułu jest spojrzenie na wybrane kwestie marketingu między innymi $\mathrm{z}$ perspektywy obecnej pandemii wywołanej koronawirusem. COVID-19 praktycznie z dnia na dzień zmienił życie ludzi na świecie. Przede wszystkim przyhamowała gospodarka, zwłaszcza odczuli to przedsiębiorcy z sektora MŚP, branża usług, gastronomii, turystyki, a w związku $\mathrm{z}$ tym uwaga oraz oczekiwania klienta skoncentrowane zostały zdecydowanie na inne aspekty - zdrowotne i higieniczno-sanitarne. Spowolniło się tempo życia, bo świat został zaskoczony i zdezorientowany, a towarzysząca temu stanowi ogromna niepewność, co będzie dalej, przewartościowała dotychczasowe priorytety w skali globalnej. Należy więc postawić tezę, iż wiele obserwowanych $\mathrm{w}$ trakcie pandemii COVID-19 zmian w zachowaniach konsumentów będzie miało charakter trwały, czego rezultatem będą głębokie i długookresowe zmiany w strategiach marketingowych przedsiębiorstw.

\section{Instrumenty marketingowe}

D la przedsiębiorstwa marketing oznacza zyskowne zaspokajanie potrzeb klientów, do czego wykorzystuje ono zbiór instrumentów, które z kolei mają służyć maksymalizacji zadowolenia konsumentów. Ważne jest nie tylko pozyskiwanie nowych, ale zatrzymywanie dotychczasowych klientów i budowanie z nimi długoterminowych relacji. $\mathrm{W}$ rozumieniu marketingu jako procesu wskazuje się na tworzenie, proponowanie oraz wymianę wartości i korzyści między uczestnikami rynku. Marketing służy każdemu podmiotowi jako mechanizm osiągania celów za pomocą dostępnych zasobów oraz celowo dobranych instrumentów i działań dostosowanych do charakteru warunków rynkowych (Garbarski i in., 2000, s. 54-72). Podstawowym instrumentem marketingowym (zasobem marketingowym, rynkowym) w każdej organizacji jest produkt. W koncepcji marketingu podkreśla się dążenie do posiadania dobrego produktu, czyli takiego, w którym wykorzystano optymalne rozwiązania techniczne i technologiczne, pamiętając przy tym, że dobry produkt może wygenerować zamierzone bądź wyższe przychody ze sprzedaży i zysk (Woźniczka i in., 2014, s. 27). Produktem jest przede wszystkim to, co można zaoferować nabywcom w celu użytkowania lub dalszego przetwarzania czy też po prostu posiadania. Mowa tu nie tylko o zwykłych dobrach materialnych i usługach, ale także o osobach, miejscach, ideach. Wymienione rodzaje produktów mogą być istotą oferty marketingowej dla określonej grupy nabywców. Wprowadzając produkt na rynek, trzeba brać pod uwagę punkt widzenia przedsiębiorstwa/podmiotu (jak zostanie odebrany, jakie niesie za sobą wartości i zyski) oraz punkt widzenia konsumenta, bo przecież to zbyt towarów potwierdza, jaką produkt cieszy się opinią wśród nabywców i jak bardzo stał się popularny. Bezpośrednio z produktem związana jest marka. Właśnie ona wyróżnia produkt na rynku. Na tworzenie marki mają wpływ takie czynniki, jak: nazwa produktu, opakowanie, cena, opinia wśród klientów, forma promocji, tradycja związana z produktem. Marka pozwala nabywcom rozpoznać producenta, zaś wiarygodna marka świadczy o poziomie jakości produktu, co przyczynia się do tego, że usatysfakcjonowany konsument poszukuje i nabywa na rynku te, a nie inne produkty. „Wartość marki jest odzwierciedleniem sposobu myślenia, odczucia i respektowania marki przez nabywców, jak również ceny udziałów w rynku i zyskowności powiązanej z marką" (Michalski, 2017, s. 246). Dobra marka może sprzyjać wzrostowi wielkości sprzedaży, ale trzeba też pamiętać o tym, że wybór nieodpowiedniej marki może dać efekt odwrotny, czyli straty, a być może nawet utratę wypracowywanego przez lata prestiżu samej organizacji.

Jak uważa D. Szwajca (2010, s. 145-146): „marka wyrobu może trwać i zyskiwać popularność przez dziesiątki lat (...). Dobre marki wspierają pozytywną reputację firmy, a także lojalność klientów". Autorka podaje następujące etapy tworzenia wartości dla klienta w połączeniu z określonymi zasobami marketingowymi: 1) definiowanie wartości (zasoby to: system informacji 
marketingowej, bazy danych), 2) kształtowanie wartości (zasób to relacje z dostawcami), 3) komunikowanie wartości (zasoby to marka i wizerunek organizacji), 4) oferowanie wartości (zasoby to rodzaj kanału dystrybucji, relacje z klientami) (Szwajca, 2010, s. 144). Do zasobów marketingowych można zaliczyć również: cenę, dystrybucję, komunikację, reputację firmy, lojalność klientów (czyli zasoby, których nie można spożytkować), a także wiedzę i kompetencje. Na uwagę zasługuje w omawianym temacie lojalność klienta. Lojalny klient dostarcza przedsiębiorstwu wielu konkretnych korzyści, dlatego że regularnie nabywa produkty danej firmy, pozytywnie się o niej wyraża, rekomendując ją innym, postrzega ją jako partnera i jest odporny na działania podmiotów konkurencyjnych. Tacy klienci w sposób dobrowolny i bezinteresowny polecają usługi i produkty danej organizacji, dlatego ich opinie są bardziej wiarygodne niż np. płatna reklama. W ten sposób lojalny klient uczestniczy w generowaniu większych zysków przedsiębiorstwa, bowiem przypisana marce jakość często stanowi podstawę do podwyższenia ceny, którą stały klient jest w stanie zaakceptować, co mimo wszystko nie naruszy pozytywnego wizerunku producenta (Szwajca, 2010, s. 148).

Cena to jeden $\mathrm{z}$ instrumentów marketingu, który jako jedyny „przybiera postać wynagrodzenia za nakłady ponoszone przez przedsiębiorstwo" i stanowi źródło jego dochodów (Garbarski i in., 2000, s. 351). Z kolei z punktu widzenia klienta cena jest wydatkiem, który musi on ponieść, by wejść w posiadanie produktu. Kupujący, patrząc na cenę, skupiają się również na jakości towaru. Polityka cenowa może opierać się na różnych strategiach, o których decydować będą zachowania nabywców i reakcje konkurentów (Garbarski i in., 2000). Do instrumentów marketingowych należy również dystrybucja. $\mathrm{Na}$ działania związane $\mathrm{z}$ dystrybucją składają się kanały dystrybucji i fizyczny przepływ towarów. Opiera się ona na współpracy dostawców i odbiorców towarów oraz pośredników, którzy zapewniają łączność producentów z odbiorcami dóbr i usług. Ta forma współdziałania, która również przynosić powinna obustronne korzyści, może przebiegać na zasadzie: zgodnej współpracy, wykształcenia się integratora kanału dystrybucji i bezpośredniego oddziaływania jednych podmiotów na zachowania innych (Garbarski i in., 2000, s. 442-456). Można wyróżnić dystrybucję intensywną (dotyczy całego rynku, czyli tych miejsc, w których klienci chętnie nabywają określony produkt), selektywną (jej istota polega na dostarczaniu produktów do nabywcy przez ograniczoną liczbę pośredników na danym rynku) i wyłączną (w tym przypadku sprzedaż danych produktów prowadzi jeden punkt na danym terenie). Istotnym instrumentem marketingowym jest również komunikacja, inaczej określana jako zespół informacji przekazywanych przez organizację nie tylko klientom, ale i innym podmiotom oraz informacji zdobytych w wyniku obserwacji samego rynku (trendy, preferencje konsumentów). Jest to specyficzna forma porozumiewania się producenta $\mathrm{z}$ członkami rynku docelowego. Jak pisze B. Pilarczyk (2015, s. 264): „komunikacja marketingowa jest celową działalnością przedsiębiorstwa o perswazyjnym charakterze, zmierzającą do kształtowania potrzeb i stymulowania popytu nabywców".

W dobie koronawirusa zmieniła się postawa konsumenta, bo na jego działania związane $\mathrm{z}$ aktywnością na rynku wpłynął inny sposób myślenia i ocena zaistniałej sytuacji. Dotychczasowy styl życia koncentrujący się na problemach częstotliwości zakupów, uczestnictwa w kręgach towarzyskich, rozrywkach, rekreacji, hobby czy sam stosunek do pracy zawodowej musiał się zmienić i to niezależnie od woli danej osoby. Ta zaskakująca sytuacja wpłynęła na zmianę osobowości klientów, która, jak stwierdzono, w normalnych warunkach zmienia się wraz z upływem lat, a dziś czas przyspieszył i zmienił nas, otoczenie, a nawet nasze życiowe cele, plany, priorytety. Uważa się, że to właśnie osobowość klienta decyduje o zakupie takich produktów, jak np. odzież, biżuteria, zdrowa żywność, samochody. Produkty nabywane przez konsumenta pomagają $\mathrm{w}$ określeniu jego osobowości (statusu społecznego) i przez to nie tylko buduje on poczucie własnej wartości, ale też wartościami tymi dzieli się z otoczeniem. Od marca tego roku nawet najbardziej wybredny klient zmuszony został do innych niż zwykle zachowań i nabywania koniecznych produktów w celu ochrony zdrowia i życia. Styl życia każdego człowieka zdominowała coraz dłuższa lista nakazów, zakazów i obostrzeń. Światowa gospodarka znalazła się w stanie zamrożenia, a teraz wszystkich łączy jeden problem - pokonanie koronawirusa, w obliczu którego mimo XXI wieku okazaliśmy się jak na razie bezradni.

\section{Działania marketingowe}

$J$ ak wiadomo, marketing zmienia zachowania, nawyki, zapatrywania jednostek i grup społecznych, system wartości pod wpływem określonych działań, nazwanych działaniami marketingowymi. Za skuteczne działania marketingowe uważa się dziś te $\mathrm{z}$ nich, które wywierają rzeczywisty, mierzalny wpływ na wynik finansowy, rentowność lub wartość przedsiębiorstwa, szczególnie poprzez zwiększanie całkowitej wartości klienta (Woźniczka i in., 2014, s. 18). Opracowanie programu działań marketingowych polega na podjęciu wielu szczegółowych decyzji, dotyczących wszelkich czynności i zadań, które powinny być realizowane, aby osiągnąć wyznaczone cele operacyjne i strategiczne. A zatem mowa tutaj o wszystkich przedsięwzięciach polegających na opracowaniu nowych lub wycofaniu dotychczasowych produktów, wprowadzaniu zmian $\mathrm{w}$ istniejących produktach, obniżaniu kosztów działalności, dokonywaniu zmian cen produktów, uruchamianiu nowych kanałów dystrybucji, wdrażaniu określonych rozwiązań logistycznych, prowadzeniu komunikacji marketingowej za pomoca reklamy lub public relations, organizowaniu systemu sprzedaży produktów itp. Typowy zakres działań marketingowych dotyczy produktu (marki), jego ceny, dystrybucji, komunikacji marketingowej, promocji (Woźniczka i in., 2014, s. 241-242).

Całokształt działań marketingowych przedsiębiorstwa składa się na jego strategię marketingową. Tworzona ona 
jest do osiągania wcześniej założonych i w miarę możliwości precyzyjnie określonych celów. Cele te powstają przed stworzeniem strategii i mogą być formułowane w kategoriach: rynkowych (np. zdobycie określonego udziału w rynku), ekonomicznych (np. zrealizowanie założonego wcześniej zysku) czy też relacyjnych, najczęściej określanych w stosunku do najbliższych konkurentów przedsiębiorstwa (Pietrasieński, 2005, s. 49-50).

Współczesne organizacje nie mogą funkcjonować na rynku bez stosowania zasad zarządzania marketingowego. Pod tym pojęciem należy rozumieć „proces planowania i realizacji pomysłów, kształtowania cen, promocji i dystrybucji towarów, usług i idei, mających doprowadzić do wymiany spełniającej oczekiwania docelowych grup klientów i organizacji” (Kotler, 1994, s. 11). Zarządzanie marketingowe jest procesem planowania i kształtowania instrumentów marketingowych: produktów, cen, dystrybucji, promocji ukierunkowanych na realizację misji i osiągania celów, do których między innymi zalicza się dostarczanie nabywcom coraz lepszych wartości stanowiących podstawę istnienia i rozwoju przedsiębiorstwa na rynku. Kwestiami tymi zajmuje się dział marketingu lub ośrodki badawcze, powołane specjalne zespoły badawcze, agencje bądź sekcje. Powyższe komórki/jednostki mają za zadanie prowadzić badania dotyczące np. preferencji konsumentów w danym czasie, prognozy sprzedaży nowego produktu, a zatem i zmiany sytuacji na rynku związanej z pojawieniem się nowego własnego produktu bądź usług i reakcji konkurencji, oceny efektywności kampanii promocyjnej. Badania polegają na systematycznym zbieraniu opinii i informacji, sondażach, wywiadach oraz ich analizie, a także kompleksowej ocenie sytuacji, na rozważeniu stawianych hipotez $\mathrm{z}$ uwzględnieniem stanu zadowolenia konsumentów, powodów zakupu, lojalności wobec marki (Michalski, 2017, s. 131-133). $\mathrm{W}$ tych badaniach i pogłębionych analizach istotne są nie tylko metody wskazywane przez zarządzanie, ale także przez statystykę, socjologię, psychologię i logikę. Popyt jako wiodący aspekt zarządzania marketingowego łączy zadanie logistyki i marketingu - dystrybucji produktu i obsługi klienta. Marketing kojarzy się głównie z działaniami mającymi na celu zyski, ale jego formy ewaluowały w stronę również niedochodowych. Dodać należy, że działania marketingowe obecnie cechują się elastycznością i niezwykłą wrażliwością na bieżące zmiany wywołane czynnikami społeczno-ekonomicznymi, technologicznymi czy też politycznymi.

W działalności marketingowej nie można pominąć wydarzeń marketingowych, które mają charakter propagandowy, integracyjny, promocyjny, charytatywny. Są one nastawione na kontakty $\mathrm{z}$ klientami, budowanie relacji między pracownikami przedsiębiorstwa/instytucji bądź między firmą a jej partnerami biznesowymi. Właśnie takie wydarzenie polega na organizacji różnorodnych akcji, podczas których następuje zacieśnienie relacji między ich uczestnikami, często między producentami a konsumentami $\mathrm{w}$ związku $\mathrm{z}$ wprowadzeniem nowej marki albo wzmocnieniem już istniejącej na rynku. Do wydarzeń marketingowych zalicza się: targi, wystawy, aukcje, giełdy, spotkania jubileuszowe. Nietrudno dostrzec, że w ostatnim czasie takie wydarzenia zostały zawieszone, obowiązuje bowiem zakaz zgromadzeń, a bezpośrednich spotkań i rozmów nie zastąpi reklama, media czy ulotka promocyjna. Zatem koronawirus znacznie osłabił skuteczność działań marketingowych, co dla przedsiębiorstw oznacza konieczność przeformułowania całych strategii marketingowych.

\section{Marketing zaangażowany społecznie}

W spółczesne przedsiębiorstwa powinny mieć na uwadze przede wszystkim interes społeczny i w ramach marketingu zaangażowanego społecznie, wspierając cele społeczne, umacniać swoją pozycję rynkową i budować swój korzystny wizerunek w otoczeniu bliższym i dalszym. Do efektów relacji z otoczeniem (zewnętrznych) można zaliczyć budowanie korzystnych opinii interesariuszy zewnętrznych, wzrost zainteresowania produktem, wzrost przychodów ze sprzedaży, możliwość zwiększania cen produktów, wzrost wartości firmy, pozyskanie nowych lub zachowania dotychczasowych inwestorów. Można zaobserwować również skutki wewnętrzne takich działań, jak: wzrost motywacji pracowników, ich odpowiedzialności i zaangażowania w procesie doskonalenia produktów, popularyzacja i akceptacja misji i strategii przedsiębiorstwa $\mathrm{z}$ akcentami na społeczną odpowiedzialność biznesu, wzrost efektów ekonomicznych prowadzonej działalności, wzrost skłonności do innowacyjnych postaw pracowników, w tym kadry zarządzającej przedsiębiorstwa. Sprzyja to doskonaleniu kultury organizacyjnej firmy i rozwoju zasobów ludzkich (Brzeziński, 2020, s. 66-67). Wdrożenie idei społecznej odpowiedzialności ma prowadzić do postrzegania przedsiębiorstwa nie tylko jako podmiotu gospodarczego, ale jako organizację społeczną, zaś działania społecznie odpowiedzialne mają służyć poszczególnym grupom interesariuszy i rozwojowi danej jednostki. Przede wszystkim społeczna odpowiedzialność biznesu (ang. Corporate Social Responsibility - CSR) niesie za sobą wiele korzyści związanych z poprawą wizerunku. Organizacje, które decydują się na przyjęcie tych zasad, stają przed koniecznością wprowadzenia wielu zmian w systemie zarządzania strategicznego czy też - w szerszym ujęciu - w strategiach marketingowych. Działania podejmowane przez pryzmat CSR uwzględniają kwestie społeczne, ekonomiczne, środowiskowe i etyczne. To efektywna strategia zarządzania, która poprzez prowadzenie dialogu społecznego na poziomie lokalnym przyczynia się do wzrostu konkurencyjności przedsiębiorstw na poziomie globalnym i jednocześnie kształtowania warunków dla zrównoważonego rozwoju społecznego i ekonomicznego, co oznacza zwiększone inwestycje w zasoby ludzkie, ochronę środowiska i relacje $\mathrm{z}$ otoczeniem.

Najwyższym poziomem społecznej odpowiedzialności jest strategia wkładu społecznego, w której przedsiębiorstwo postrzega siebie jako składową życia społecznego i aktywnie poszukuje możliwości działań na rzecz dobrobytu społecznego i podejmuje wiele działań 
dla ochrony środowiska naturalnego (Brzeziński, 2017, s. 188). Jak zauważają M. Jakubiec i A. Jakubczak (2018, s. 58-63): „społeczna odpowiedzialność nie stanowi tylko szumu promocyjnego, nie służy tylko budowaniu wartości medialnej przedsiębiorstwa, choć dla kreowania wizerunku firmy jest bardzo istotna, ale jest także nakierowana na podejmowanie aktywności dotyczącej rozwiązywania problemów społecznych". W ramach koncepcji CSR stosuje się działania związane $\mathrm{z}$ ochroną środowiska, przestrzeganiem praw konsumenta czy też polityką równych szans w zakresie zatrudnienia i respektowania praw pracowniczych, nową wizją partnerstwa. CSR jest oparta na standardach etycznych, poprzez które przedsiębiorstwa uwzględniają w swoich działaniach aspekty ekologiczne i społeczne, dostrzegając nie tylko potrzeby indywidualnego konsumenta, ale też społeczeństwa jako całości. Na tej podstawie powstała idea marketingu społecznego, a jedną z jego odmian jest tzw. zielony marketing, uwzględniający kwestie związane $\mathrm{z}$ ochroną środowiska. Poza tym marketing społeczny jest skoncentrowany na zrównoważonej konsumpcji polegającej na propagowaniu zdrowego trybu życia, niezagrażającego przyszłym pokoleniom (Sławińska, 2015, s. 22-25). Koncepcje CSR można analizować dwojako: po pierwsze jako działania mające na celu zmniejszenie negatywnego oddziaływania przedsiębiorstwa na wszystkie grupy interesariuszy, a po drugie jako działania pozwalające w przyszłości uniknąć negatywnych konsekwencji prowadzonej przez przedsiębiorstwo działalności. Taka polityka gwarantuje ochronę interesu własnego, a także przyczynia się do pomnażania dobrobytu społecznego (Lulewicz-Sas, 2016, s. 37-42). Jak pisze A. Brzeziński (2017, s. 186-195), koncepcja społecznej odpowiedzialności polega na realizacji celów ekonomicznych poprzez strategie prośrodowiskowe prowadzące do zrównoważenia korzyści ekologicznych i kosztów ekonomicznych (tzw. ekobilans). Obecnie idea ta jest powszechnie znana, a odpowiedzialny biznes stał się zjawiskiem globalnym (tendencją światową), bowiem jego głównym celem jest troska o losy kolejnych pokoleń.

\section{Podsumowanie}

W obecnym "galopującym” świecie w dobie globalizacji, nowych technologii, w tym informatycznych, Internetu, nowych standardów społecznych wszystko ma swoją wartość. Procesy globalizacyjne przyspieszają nie tylko w obszarze techniki i gospodarki, ale także w sferze mentalnej. Dynamikę zmian dostrzec można zarówno na rynkach towarów i usług, w przemyśle, w sferze technologii i wiedzy, jak i wzorców konsumpcyjnych i kultury masowej. Dziś w biznesie czy w zwykłym życiu już na etapie podejmowania decyzji klient stawia sobie pytanie: jaką inwestycja ma wartość, czy ona na pewno będzie korzystna. Rzecz dotyczy nie tylko produktu (tworzenia, wdrażania czy zakupu), który sam w sobie ma wartość i dla producenta i dla nabywcy, cenna jest także odpowiednia argumentacja słowna, obrazowy język (komunikacja marketingowa), idea, symbole, hasła. To praktycznie niemierzalne narzędzia marketingowe, mające w sobie "tajemną" moc, ale często są skuteczne i mają pozytywny oddźwięk. Globalizacja jest ważnym czynnikiem dynamizującym rozwój rynku konsumpcyjnego. Globalne przedsiębiorstwa poprzez swoje produkty wpływają na kształtowanie się wzorów zachowań i systemów wartości, które z kolei tworzą profil konsumenta. Oprócz klientów coraz większego znaczenia $\mathrm{w}$ marketingu nabierają różne grupy interesariuszy: pracownicy, udziałowcy, społeczności lokalne i wirtualne, akcjonariusze (inwestorzy), menedżerowie, partnerzy w biznesie czy konkurenci, media.

W obecnych czasach wszyscy interesariusze mają na uwadze jakość produktu i usług, które przynosić będą zyski zarówno dla strony sprzedającej/promującej, jak i nabywającej. W relacjach tych lista wartości tak osobowych, jak też moralnych jest długa: uczciwość, odpowiedzialność, rzetelność, lojalność, dotrzymywanie umów, przestrzeganie prawa, umiejętność współpracy, wysokie standardy towarów i usług. Należy pamiętać, że $\mathrm{w}$ marketingu każdy podmiot zaangażowany $\mathrm{w}$ proces wymiany kreuje wartość produktu, z tym że interes każdej ze stron jest inny. Konsument, nabywając produkt, zaspokaja swoje potrzeby, zaś organizacja (przedsiębiorca), zdobywając rynki i zaufanie do swojego asortymentu (marki), patrzy na wszystkie działania z perspektywy oczekiwanych korzyści. Nieodzowna jest w działaniach marketingowych również wyobraźnia, odwaga, otwartość oraz umiejętność podejmowania i kalkulowania ryzyka, by utrzymać i zadowolić lojalnego klienta, a przy tym pozyskać przewagę konkurencyjną na tak obecnie niepewnym i nieprzewidywalnym rynku.

Nowe trendy marketingu znajdują swój wyraz w uwzględnianiu aspektów społecznych, kulturowych, ekologicznych, wynikających ze zmian zachowań nabywców, o czym powinny pamiętać współczesne organizacje. Przedsiębiorstwa, jak pokazują prawa rynku, nie mogą skupiać się jedynie na celach biznesowych. Cele te należy integrować $\mathrm{z}$ celami społecznymi i środowiskowymi w sposób przyczyniający się do rozwiązywania problemów społecznych, co w konsekwencji przyniesie zyski marketingowe, przekładające się na ostateczne wyniki finansowe i budowanie przewagi konkurencyjnej. Jak dotąd pomocne w tych dążeniach były strategie, modele biznesu, kampanie reklamowe czy inne akcje promocyjne, które, jak już wspomniano, obecnie należy zweryfikować, bowiem koronawirus spowodował ogromne zmiany $\mathrm{w}$ dotychczasowych wypracowanych i sprawdzonych mechanizmach oraz standardach życia ludzi na całym świecie i nie zamierza odpuścić. A gdy to już nastąpi, Polska, Europa i reszta świata $z$ innej perspektywy analizować będą kryteria funkcjonowania marketingu na globalnym rynku.

Znaczna część, traktowanych obecnie jako doraźne, działań marketingowych wymuszonych przez pandemię COVID-19 będzie miała charakter trwały, co spowoduje długookresowe zmiany $\mathrm{w}$ strategiach marketingowych przedsiębiorstw. 
Epidemia COVID-19, która rozpoczęła się w Chinach w końcu 2019 roku, prowadzi nieodłącznie - zdaniem autora - do końca epoki obecnej globalizacji, charakteryzującej się dynamiczną wymianą handlową, mobilnością firm, kapitału i pracowników, gwałtownym rozwojem globalnej turystyki oraz niebywałym w dziejach współczesnej cywilizacji tempem umiędzynarodowienia przedsiębiorstw. Nawet pobieżne badanie dostępnych raportów dotyczących funkcjonowania światowej gospodarki w pierwszych miesiącach roku 2020 pozwala wyciągnąć oczywisty wniosek, że rozpoczął się proces jej recesji, który jest już bardzo głęboki i może być wieloletni. Skutki tego odczuwają również polskie przedsiębiorstwa. Przeprowadzone przez autora telefoniczne wywiady pogłębione z kierownictwem wyższego szczebla wybranych losowo firm sektora energetycznego, sektora budowlanego, w tym deweloperskiego, oraz firm handlowych wykazały, że żadna $\mathrm{z}$ badanych firm nie posiada programu funkcjonowania w warunkach epidemii COVID-19. Wskazuje to, iż światowa gospodarka stoi na rozdrożu i właściwie wszystko zależy od tego, kiedy ludzkość upora się z epidemią koronawirusa.

\section{prof. dr hab. Stanisław Brzeziński \\ Akademia Ekonomiczno-Humanistyczna w Warszawie \\ ORCID: 0000-0001-5737-6891 \\ e-mail: stanislaw_brzezinski@wp.pl}

\section{Bibliografia}

[1] Brzeziński A. (2017), Społeczna odpowiedzialność przedsiębiorstwa w ocenie pracowników, [w:] J. Nowakowska-Grunt, J. Kabus, (red.), Wyzwania i perspektywy współczesnej organizacji. Kontekst gospodarczy i publiczny, Wydawnictwo Wydziału Zarządzania Politechniki Częstochowskiej, Częstochowa, s. 186-195.

[2] Brzeziński S. (2020), Marketing, logistyka, finanse a społeczna odpowiedzialność biznesu, Wydawnictwo Politechniki Częstochowskiej, Częstochowa.

[3] Buchajewska-Wróbel M., Wendt R., Rytka E., Gasparski J., Gajda K. (2011), Menedżer do zadań specjalnych. Czasowe zarządzanie przedsiębiorstwem, Helion, Gliwice.

[4] Garbarski L., Rutkowski I., Wrzosek W. (2000), Marketing. Punkt zwrotny nowoczesnej firmy, Polskie Wydawnictwo Ekonomiczne, Warszawa.

[5] Jakubiec M., Jakubczak A. (2018), Realizacja działań społecznie odpowiedzialnych: zasoby i studium przypadku, „Przegląd Organizacji”, Nr 1, s. 58-63.

[6] Kotler P. (1994), Marketing. Analiza, planowanie, wdrażanie $i$ kontrola, Gebethner i Ska, Warszawa.

[7] Lulewicz-Sas A. (2016), Identyfikacja działań społecznie odpowiedzialnych $w$ obszarze funkcjonowania przedsiębiorstwa, „Przegląd Organizacji”, Nr 5, s. 37-42.

[8] Michalski E. (2017), Marketing. Podręcznik akademicki, Wyd. II, Wydawnictwo Naukowe PWN, Warszawa.

[9] Pabian A. (2005), Marketing szkoly wyższej, Oficyna Wydawnicza ASPRA-JR, Warszawa.
[10] Pietrasieński P. (2005), Międzynarodowe strategie marketingowe, Polskie Wydawnictwo Ekonomiczne, Warszawa.

[11] Pilarczyk B. (2015), Sposoby komunikacji masowej, [w:] H. Mruk, B. Pilarczyk, M. Sławińska, Marketing. Koncepcje - Strategie - Trendy, Wydawnictwo Uniwersytetu Ekonomicznego w Poznaniu, Poznań, s. 264-298.

[12] Sławińska M. (2015), Istota i znaczenie marketingu $w$ zarządzaniu przedsiębiorstwem, [w:] H. Mruk, B. Pilarczyk, M. Sławińska, Marketing. Koncepcje - Strategie - Trendy, Wydawnictwo Uniwersytetu Ekonomicznego w Poznaniu, Poznań, s. 11-33.

[13] Stachowicz-Stanusch A. (2007), Potegga wartości. Jak zbudować nieśmiertelna firmę, Helion, Gliwice.

[14] Szwajca D. (2010), Zasoby marketingowe w procesie budowania globalnej konkurencyjności współczesnych przedsiębiorstw, [w:] W. Caputa, D. Szwajca (red.), Potencjat konkurencyjny przedsiębiorstwa $w$ warunkach globalizacji, CeDeWu.pl, Warszawa, s. 137-152.

[15] Woźniczka J., Hajdas M., Kowal W. (2014), Zarządzanie marketingiem, Wydawnictwo Uniwersytetu Ekonomicznego we Wrocławiu, Wrocław.

\section{Marketing as a Value Creating Process in the Time of the COVID-19 Pandemic}

\section{Summary}

Marketing in general means a way of approaching a business, while in functional terms it consists in identifying the customer's needs and then determining which of them to satisfy to the highest degree by creating and proposing appropriate products or services. A set of marketing instruments is used to implement these activities. Therefore, companies undertake marketing activities aimed at the target market, primarily with the customer's benefit in mind. Although the expenditures for marketing purposes are huge, organizations decide on these costs in order to meet the consumer's needs and gain a competitive advantage.

Today, the client knows his value, therefore he pays attention to all aspects of the purchased products (brands) and expects that both the price and quality will satisfy him, being aware that he is also of value for the manufacturer. Recent events related to the emergence of the coronavirus led to a freezing of the global economy, and the existing standards of our quality of life, and thus consumer behavior, had to change. In the article, the author tries to show, using the example of marketing as a process of creating value, how the current situation re-evaluates priorities in the consumer market and changes us as buyers in the mental sphere.

The author makes a thesis that many of the changes in consumer behavior observed during the COVID-19 will be permanent and, as a result, will result in profound and long-term changes in corporate marketing strategies.

\section{Keywords}

marketing, value creation processes, consumer behavior, new trends of marketing, COVID-19 